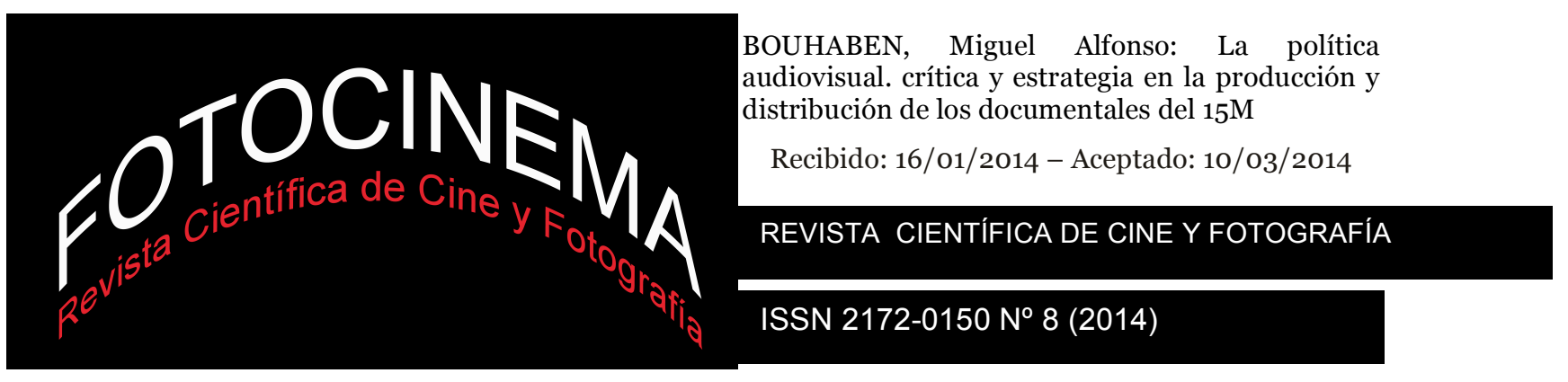

\title{
LA POLÍTICA AUDIOVISUAL. CRÍTICA Y ESTRATEGIA EN LA PRODUCCIÓN Y DISTRIBUCIÓN DE LOS DOCUMENTALES DEL 15M
}

\section{AUDIOVISUAL POLICY. CRITICISM AND STRATEGY IN PRODUCTION AND DISTRIBUTION OF DOCUMENTARIES ON 15M}

\author{
Miguel Alfonso Bouhaben \\ Universidad Complutense de Madrid
}

\begin{abstract}
Resumen:
Tras las crisis sociales acaecidas en los últimos años aparece un nuevo movimiento social posicionado críticamente contra las corporaciones económicas y contra la clase política: el 15M. Sus reivindicaciones giran en torno a una mayor participación de la ciudadanía en los asuntos públicos y sus formas de organización adoptan una estructura no jerarquizada, horizontal, abierta $\mathrm{y}$ colectiva. El objetivo de este artículo es valorar las coherencias e incoherencias que se dan entre esta forma de democracia participativa $\mathrm{y}$ las formas de los documentales producidos sobre el movimiento hasta la fecha. Para ello, analizaremos las formas de producción y de distribución de estos documentos audiovisuales desde dos perspectivas: una crítica contra las formas de algunos documentales que conservan todavía los recursos visuales y estructuras del aparato ideológico contra el que combaten; y otra estratégica que aporte ideas sobre los dispositivos estéticos y narrativos que deberían de tener estos productos audiovisuales para ser coherentes con los dispositivos políticos del movimiento $15 \mathrm{M}$.
\end{abstract}

\begin{abstract}
:
Following the social crises that occurred in recent years a new social movement against economic critically positioned corporations and against the political class appears. His claims revolve around increased participation of citizens in public affairs and their forms of organization adopted a non- hierarchical, horizontal, open and collective structure. The objective of this paper is to assess the consistencies and inconsistencies that exist between this form of participatory democracy and forms of documentaries produced to date. To do this, we will analyze the forms of production and distribution of these audiovisual documents from two perspectives: a critique of some forms of documentaries that still retain visual resources and structures of the ideological apparatus against fighting, and another that provides strategic ideas aesthetic and narrative devices should have these audiovisual.
\end{abstract}

\section{Palabras clave:}

Documentales del 15M; Producción audiovisual; Distribución audiovisual; Enunciación colectiva; Representación múltiple; Narración abierta

Keywords:

Documentary 15M; Audiovisual production; Audiovisual distribution; Collective enunciation; Multiple representation; Open Narration 


\section{Introducción}

Toda obra de arte es hija de su tiempo. A lo largo de la Historia, los procesos y modelos de producción artística han estado vinculados y determinados por las prácticas sociales, las circunstancias culturales y las determinaciones económicas. De alguna manera todo arte es político ya que se inserta en una matriz social y cultural que hace posible ese modo de expresión. Ahora bien, habría que valorar la diferencia sustancial que se establece entre las formas artísticas de la política oficial -como conjunto de producciones que las instituciones regulan y subvencionan con vista a producir un efecto de control, creación de hábitos, normalización o alienación de la vida de los ciudadanos- y las formas de lo político -como aquellas otras liberadas de cualquier regulación estatal o servilismo. Estas formas artísticas de contestación que configuran el campo de lo político son las que usan los ciudadanos contra los abusos de la política oficial. Es verdad que los paladines del “arte por el arte” podrían reprochar un exceso de radicalidad en esta dicotomía ya que para ellos puede haber estética sin política, poética sin ética y arte sin responsabilidad ni compromiso social. No cabe duda que la posición supuestamente apolítica de los apologetas del arte por el arte es profundamente política. No tomar partido o no decidir en cualquier ámbito de la vida supone ya irremisiblemente un acto de decisión. Como asegura el Colectivo Wu Ming: "El que crea no puede de manera alguna abstenerse, dejar de intervenir. Escribir ya es producir, narrar ya es política” (Wu ming, 2002, p. 30)

El caso es que toda producción artística (pictórica, arquitectónica, narrativa, etc.) emerge en un campo político, en una formación social. Es esta formación social la que define como han de ser las producciones artísticas, y estas, a su vez, han de reproducir la ideología dominante de dicha formación social ya que "toda formación social, al mismo tiempo que produce y para poder producir, debe reproducir las condiciones de su producción” (Althusser, 1975, p. 9). Así, la formación social con-forma la producción artística. Si a modo de ejemplo retrotraemos nuestra mirada a la formas de narración que han utilizado como medio de expresión la filosofía, y las relacionamos con la formación social en la que emergen, no tiene que resultar una sorpresa que nos encontremos 
estructuras comunes. Es, justamente, porque reproducen en su estructura la formación social en la que aparecen¹.

Teniendo en cuenta estas cuestiones en torno a la producción artística cabe preguntarse: ¿Cómo deben ser las formas artísticas de nuestro convulso tiempo histórico? ¿Puede el arte anticipar formas de organización política tras las crisis acaecidas en la actualidad? Sin duda, toda crisis tiene algo de catártico y de renovación de las estructuras dominantes de una sociedad. El movimiento de contestación social del 15M ha traído a escena una nueva forma de construcción política que nace de la crisis tanto de los modos de organización política basados en la representatividad como de las prácticas económicas del capitalismo globalizado asentadas en la competitividad más brutal. Los derechos más básicos se han ido empobreciendo con las medidas adoptadas por la clase política que, por sus decisiones, parece rendir cuentas en exclusiva a los diseñadores de la economía mundial más que a las peticiones de la soberanía popular. El sistema económico capitalista ha invadido por completo la vida de una ciudadanía que está, y en esto palabra la inteligencia común da en el clavo: indignada. Por ello, el movimiento $15 \mathrm{M}$ ha hecho un esfuerzo por renombrar la democracia volviendo a la esencia griega: una democracia participativa donde todas las voces valgan por igual y donde las decisiones sean adoptadas en asamblea, desde la más absoluta horizontalidad.

Nuestra actitud respecto este nuevo movimiento es muy positiva. De hecho, la motivación última de este artículo no es otra que la de indagar y presentar nuevas formas de representación audiovisual más democráticas y participativas.

\section{Metodología}

En el presente artículo no se trata de desentrañar los modos de organización política del movimiento $15 \mathrm{M}$, sino que lo que pretendemos es más bien

1. ¿Por qué Platón escribe sus obras en forma de diálogo? Porque emerge en el seno de una formación social definida como una democracia participativa donde la práctica política habitual era la discusión y el diálogo en el ágora sobre las cuestiones públicas. ¿Por qué Descartes escribe en forma de monólogo? Porque aparece en un momento donde la formación social está virando hacia la emancipación del ser humano del yugo opresor del Antiguo Régimen. 
observar, analizar y criticar los modos de producción audiovisual vinculados o inspirados en dicho movimiento de cara a determinar un nuevo modelo estético y narrativo. Es decir, se trata de estudiar si en las producciones audiovisuales del $15 \mathrm{M}$ se cumplen las características inherentes al movimiento: ¿Son capaces de montar una narración con una multiplicidad de voces, una narración sostenida por una enunciación de tipo colectivo? ¿Están dichas voces en un mismo plano de igualdad y horizontalidad? ¿Su modo de narración es abierto y está en continua mutación al igual que la estructura estructurante que se moviliza en las asambleas? ¿Son narraciones que rompen la linealidad y el ordenamiento jerárquico del relato clásico? ¿Rompen con el concepto de autoría y apuestan por el anonimato? ¿Su distribución y su consumo son también democráticos? ¿Hay ánimo de lucro? La respuesta a estas preguntas deberían de darnos la clave para entender si en este espacio político se está abriendo un camino a nuevos modelos de narratividad o si por el contrario no es más que un proyecto que repite tentativas de ruptura pretéritas.

Por ello, el método que vamos a poner en práctica va a consistir en analizar si hay una correlación estructural entre los modelos de producción y distribución audiovisual de este movimiento social y su conformación política. Es decir, se trata de observar si en los documentales producidos por este movimiento encontramos las algunas huellas del modelo de organización política propuesto: horizontalidad, multiplicidad, anonimato, work in progress. Estas obras artísticas deberían de reproducir el modo de organización política tanto en su producción, como en su distribución y recepción algo que como mostraremos no siempre ocurre. Por ello, nuestra finalidad es doble. En primer lugar, se trata de realizar una crítica de aquellas formas que no reproduzcan el contenido de la formación social. $\mathrm{Y}$ en segundo lugar, plantear algunas estrategias de producción que se han dado en la historia del audiovisual que sí se adecuan a los procesos de conformación política y que pueden servir de paradigma estético y narrativo para que futuras creaciones resulten coherentes con el ideario de esta acción social. 


\section{Marco teórico}

Sobre los trabajos audiovisuales del $15 \mathrm{M}$ no hay ningún estudio científico completo y sistemático. La bibliografía es casi inexistente y se reduce a un especial que publicó la revista Cahiers du Cinéma España en su número 47, donde algunos cineastas militantes ofrecían su visión de lo que debería ser el cine del 15M, y a algunos textos de Gerardo Tudurí que podemos encontrar en su libro La politica de la colectividad (2012). Por ello, la trama teórica sobre la que apoyaremos nuestras pesquisas está configurada, en primer lugar, por trabajos e investigaciones multidisciplinares del campo de la filosofía, la lingüística, la sociología y la teoría del arte que han ido forjando conceptos ligados a las prácticas de contestación política del 15M y, en segundo lugar, por algunas de las teorías y prácticas fílmicas más relevantes del cine político y antropológico que pueden servir de referentes a futuras obras que pretendan visibilizar la problemática social inherente a este movimiento político.

Dentro del ámbito de la filosofía, el pensamiento de Gilles Deleuze (2000, 2004) nos ha servido no sólo para entender la dinámica del movimiento, sino también para configurar una posible estética y una poética del cine del $15 \mathrm{M}$, basada en los conceptos de enunciación colectiva, multiplicidad y rizoma, que rompe con aquella que encontramos en los relatos clásicos y que se define por una marca subjetiva a nivel enunciativo y por una estructura unitaria y arbórea a nivel narrativo. De la filosofía de Louis Althusser (1975) hemos recogido la importancia de la relación entre la producción y la reproducción ideológica. Asimismo, el concepto de multitud de Antonio Negri (2006) ha sido clave para explicar una de las tesis fundamentales del $15 \mathrm{M}$ sobre todo aquella que considera que el poder político es la suma de una pluralidad de voces diferentes pero comunes. Respecto a las cuestiones lingüísticas, debemos indicar la importancia que han tenido en nuestro estudio tanto los conceptos de Roland Barthes (2001, 2009) de grano de voz -aplicado al análisis de la voz en off en los documentales- y de estructura estructurante -aplicado al análisis de la estructura narrativa- como la crítica de Julia Kristeva (2001) a las estructuras narrativas lineales y su defensa de un modelo textual no centrado. Del campo de la sociología hemos centrado nuestra atención en algunos estudios de Mario 
Tascón y Yolanda Quintana (2012), Paul Virilio (2005) y David de Ugarte (2007) sobre el uso de las nuevas tecnologías como forma de contestación política y como espacio de difusión de las creaciones audiovisuales, mientras que del campo de la teoría del arte hemos seguido a José Luis Brea (2002) a la hora de entender las relaciones entre producción artística y nuevos medios de comunicación

Aparte de esta trama teórica, ha sido necesario acudir a algunas propuestas fílmicas para vislumbrar elementos afines a las prácticas políticas del 15M. Del cine de Jean-Luc Godard hemos arrojado luz sobre su trabajo dialógico en la banda de sonido de cara a mostrar de qué modo producir una enunciación colectiva, así como sobre su metodología para mostrar relaciones entre imágenes. La teoría del cine-ojo de Dziga Vertov también nos ha servido para indicar las múltiples posibilidades del cine a la hora de representar cuestiones sociales, indicando la especial importancia que tiene en el cineasta ruso captar las imágenes de cualquier lugar. Asimismo, la antropología visual de Jean Rouch y el cine-tren de Aleksandr Ivanovitch Medvedkin nos han aportado mecanismos para hacer del cine un un espacio de discusión política en constante reformulación.

De este modo, en la relación entre ambos ámbitos encontraremos las claves para analizar de manera crítica y estratégica los modelos de producción y distribución de las creaciones audiovisuales del 15M.

\section{Crítica y estrategia en la producción de los documentales del 15M}

Para analizar los documentales del 15M -apuntemos que tan sólo estudiaremos aquellos que han sido distribuidos con licencia libre por internet y, en este sentido, obviaremos aquellos otros subvencionados o que tienen una finalidad comercial- vamos a partir de tres características definitorias del movimiento político con la idea de ver los ajustes o desajustes que se producen entre la realidad política y su modo de reproducción audiovisual: la enunciación colectiva, la representación múltiple y la narración abierta. 


\subsection{Enunciación colectiva}

Si el movimiento $15 \mathrm{M}$ se define como un movimiento de voces plurales convergentes y ajenas a toda jerarquización y representatividad, entonces lo coherente sería realizar producciones audiovisuales cuyas narraciones estuviesen sostenidas por una voz múltiple, anónima y poliédrica siguiendo la lógica de muchos creadores contemporáneos que han encontrado en el crowdsourcing una útil herramienta de producción colectiva. Las imágenes del 15M deberían estar recogidas y registradas por una multitud de cineastasmilitantes, por una maraña de observadores anónimos, y no por uno sólo sujeto configurador del discurso, como ocurre en la mayoría de los documentales aparecidos hasta la fecha sobre este insólito movimiento social. Si lo que se pretende es hacer escuchar la razón común, la voz plural de la multitud rebelada contra los abusos de la clase política y los delirios de las corporaciones económicas, entonces es imprescindible ponerla en práctica en las producciones audiovisuales. Resulta en todo punto contradictorio que sean individuos concretos los que porten, desde su unicidad constitutiva, lo plural de las multitudes.

Esta contradicción nos lleva a afirmar que una de las formas básicas que tendría que tener un producto audiovisual del $15 \mathrm{M}$ sería la forma de una enunciación colectiva que partiese de configurar lo común de manera polimorfa. No se trata simplemente de construir un relato audiovisual con enunciados diversos. Es cierto que la mayoría de los documentos audiovisuales contienen enunciados pronunciados por los diversos sujetos entrevistados, incluso muchos de ellos dan voz a un amplio abanico de ciudadanos. Es el caso de 15M. En nombre de la democracia (Fernando Santise, 2011) que en sus recoge la opinión de profesores de universidad, periodistas -algunos de ellos de una ideología contraria a la del movimiento- activistas, gente anónima ${ }^{2}$, etc. No se trata de configurar, como en

2. Las entrevistas realizadas son las siguientes: Víctor Sampedro (Presidente Asociación Tabacalera y catedrático Opinión Pública URJC), Rita Maestre (Miembro de Juventud sin futuro), José Luis Roig (Periodista La Gaceta), Antonio Rubio (Periodista El Mundo), Lara Hernández (Miembro Comisión de Comunicación 15-M), Mirta Núñez (Profesora titular e invesigadora en la UCM), Juan Diego Botto (Actor), Ángel Córdoba y Juana León (Miembros Comisión de Mayores 15-M) y M Jasé Enríquez y Ángeles Ruiz (Participantes 15-M y Solfónica). 
este y en casi todos los casos, una suma de enunciados, sino de una enunciación plural.

Para lograr este objetivo una de las nociones que hay que combatir es la noción de autor. Este combate no es nuevo. El estructuralismo y el postestructualismo han terminado por destruir la idea de sujeto moderno que sin duda es inherente a la noción de autor y que había imperado desde René Descartes. El concepto de multitud de Antonio Negri (2006), las estrategias anónimas de producción del colectivo Wu Ming (2002) o la tentativa de un Cine sin Autor de Gerardo Tudurí (2012), ya en el ámbito propiamente cinematográfico, explicitan esta destrucción de la idea de autor que ya pusieran en marcha pensadores postestructuralistas de la talla de Michel Foucault y Gilles Deleuze. Michel Foucault (2002) apunta a la dimensión ideológica, reguladora y elitista de la función autor. Gilles Deleuze, por su parte, define la función del autor como una estructura donde "X explica X, firmado X", mientras que la función de la enunciación colectiva la describe como "X explica Y, formado Z" (2004, p.23). Esta función de la enunciación colectiva, sin duda, pone en marcha una suerte de multilingüísmo donde están contenidas la mayor cantidad de voces, los diferentes matices, las diferentes tonalidades. Es una manera de disolver la identidad en pro de una diferencia en diferenciación permanente y de un discurso múltiple que no reside en los sujetos enunciadores o autores sino que se sitúa entre ellos: en el intermezzo.

Estos procesos de enunciación colectiva se pueden observar en el modo de estructuración de las asambleas del $15 \mathrm{M}$ pero no en sus producciones audiovisuales. Cuando en las asambleas se propone una idea siempre es sometida a sufragio por el conjunto de los participantes. En el caso de que haya disensos, entonces se hace el esfuerzo de que esos matices o puntos de vista divergentes de cada participante hagan de la idea primera una idea más rica en determinaciones. Y así hasta que el consenso sea definitivo. De modo paralelo, lo relevante de las nuevas narrativas que emerjan de este nuevo proceso de configuración política deben ser los intersticios, es decir, los lugares de conexión, las junturas como lugar de lo común. Y ese lugar es el lugar del 
pensamiento, de lo nuevo y del devenir: una zona de creación-construcción donde la variedad de voces entran en comunión.

Si nos centramos ahora en el análisis de la enunciación de los documentales del 15M descubrimos que la mayoría de ellos están articulados que por una voz en off singular y unidireccional que esquiva $\mathrm{y}$ da de lado a las prácticas asamblearias. A pesar de esforzarse por mostrar lo común, la mayoría de ellos no se desprende de la noción de autor. Para apoyar nuestra argumentación veamos tres usos diferentes de la voz en off que denominaremos como uso emocional, uso neutro y uso pseudodialógico.

El primer uso, el emocional, lo encontramos en Excelente. Revulsivo. Importante. Una visión muy personal del 15M (S. Grueso, 2012). Este documental -que lleva por título las palabras con las que el economista José Luis Sampedro definía este movimiento social- no oculta su carácter singular y personal. Se trata de una visión particular del movimiento 15M donde el autor recorre aspectos de su militancia personal y nos pone en antecedentes de cómo y porqué apoya y participa en esta movilización reivindicativa con un marcado tono autobiográfico y emocional que revela el compromiso del autor con las movilizaciones.

El segundo uso de voz en off lo encontramos en la mayoría de las producciones audiovisuales del 15M. Estas siguen un uso neutro de enunciación donde el agente es un sólo sujeto con una voz muy plana y objetiva, casi periodística, que no dispone de ritmo ni emoción. En 15M. La revolución como una de las Bellas Artes (Iván Cuevas, 2011), por ejemplo, aparece esta voz en off neutra muy cercana al reportaje y que, además, no es más que una excusa para promocionar un libro colectivo de un grupo de estudiantes de filosofía, liderados por la profesora Teresa Oñate, sobre el $15 \mathrm{M}$. Otro ejemplo más de contenido o temática sobre lo común pero con forma singular, desde una perspectiva unilateral que está más cerca de lo que estudiosos del documental como Bill Nichols (1997) definen como la Voice of God, esa instancia autorizada y todopoderosa que va dirigiendo la mirada del espectador, que lo esclaviza y lo 
somete mediante un didactismo obsceno que sin duda es contrario a las propuestas emancipatorias promulgadas por este movimiento contestatario.

En Docuindignados (Anónimo, 2011) se pone en marcha un uso pseudodialógico y en cierta medida se manifiesta un esfuerzo por salir de la lógica de la unidireccionalidad en la voz en off. En este documental son dos sujetos, hombre y mujer, los que acompañan las imágenes con sus palabras. Esta estrategia es la que más se acerca a una posible enunciación colectiva. Ahora bien, las palabras enunciadas por estos dos sujetos no brotan de manera espontánea y emocional. Son dos actores que leen un texto de manera lineal, artificiosa e impostada. Es un falso dialogismo el que allí se manifiesta y, en consecuencia, no encontramos sensación de crítica ya que el modo expositivo resulta demasiado retórico y hueco. Falta en este uso enunciativo lo que llamaba Roland Barthes el grano de la voz que no es otra cosa que una producción melódica y lingüística que emerge del fondo del cuerpo (2009, p. 310).

La pregunta que podemos hacernos a la luz de estos ejemplos es: ¿Cómo configurar una enunciación colectiva audiovisual que sea coherente con este proceso generador de ideas que se da en las asambleas y en las movilizaciones? La mejor manera de responder a esta pregunta es acudiendo a las teorías y prácticas audiovisuales que ya hayan planteado con anterioridad estas problemáticas. Vamos a recorrer, por tanto, de modo sumario, dos de estas estrategias de conformación de una enunciación plural que deberían de ser un referente para futuros documentalistas del 15M.

La primera estrategia para componer una enunciación colectiva se puede llevar a cabo situando una multiplicidad de voces en la banda de sonido, las cuales sean ricas en matices, veraces y no impostadas. Pero, además, es necesario que estas voces no se empleen para comentar sin más la imagen. Por el contrario, han de componerse de tal manera que generen un contrapunto con la banda de imagen. En Ici et ailleurs (Jean-Luc Godard, 1974) podemos encontrar estos dispositivos dialógicos de enunciación, en la tercera parte de la película, ya que su máxima preocupación no es otra que la de conjugar la enunciación del yo (Godard) con la del tú (Mièville) y con la del él (los Palestinos que Godard había 
filmado y que, en el momento de afrontar el proceso de montaje, habían muerto). Godard y Mièville dialogan sobre las imágenes y no siempre están de acuerdo. Podemos observar como se producen disgresiones, discusiones y derivas dialécticas en las antípodas de la Voice of God de los documentales clásicos. Según Serge Daney "La tercera parte de la película vuelva a las imágenes del principio. Pero con un cambio dialéctico. Ya no hay una sino dos voces en off que se toman el tiempo de volver a ver las imágenes (como en una mesa de montaje) para ver entre los dos lo que realmente están diciendo y lo que está equivocado, para escuchar esas imágenes" (2012). Sin duda en este film del cineasta francés se da lo que Mijaíl Bajtin llama heterofonía, es decir, una multiplicidad de voces que potencia que sea el espectador el que las haga converger mediante un trabajo de lectura (Caicedo, 2003).

La segunda estrategia es la que se llevaría a cabo en la banda de imagen. Esta estrategia sí que se cumple y casi podemos decir que es una de las premisas básicas de los documentales del 15M. De modo similar al trabajo en la banda del sonido, la composición de una enunciación colectiva se realiza a de partir de materiales o cine-documentos registrados por una multitud de camarógrafos, desde múltiples perspectivas, que se ponen al servicio del común. Esta propuesta no es nueva. Ya fue puesta en práctica por Dziga Vertov y tiene como base metodológica su propia teoría del cine-ojo que pretendía poner el ojocámara en "cualquier lugar" de lo real (2011, p.178). Toda una praxis de la ubicuidad como muestran los fotogramas 1-4.
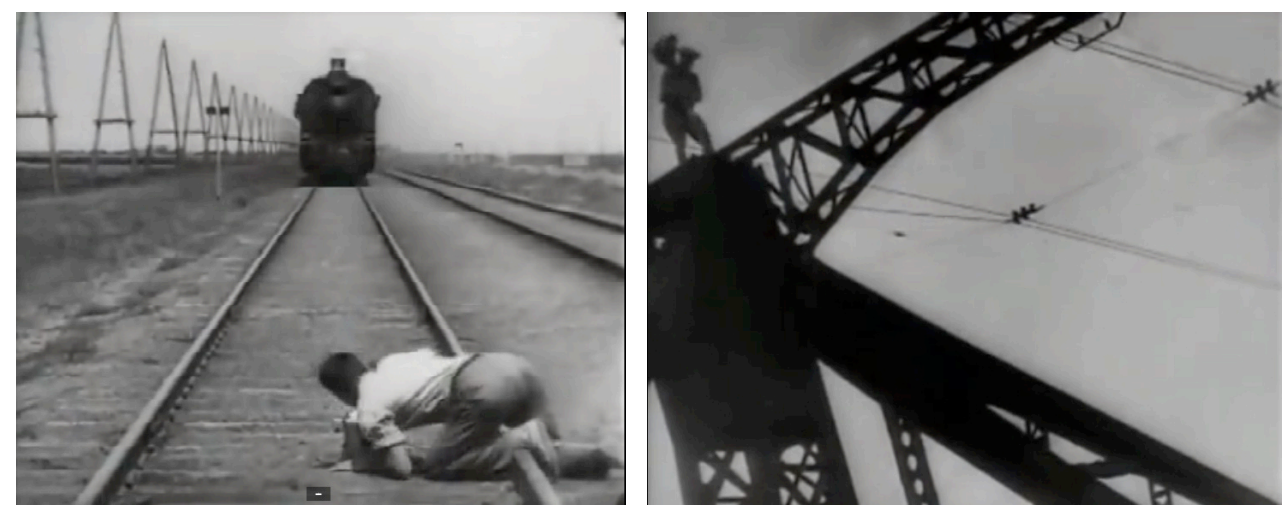

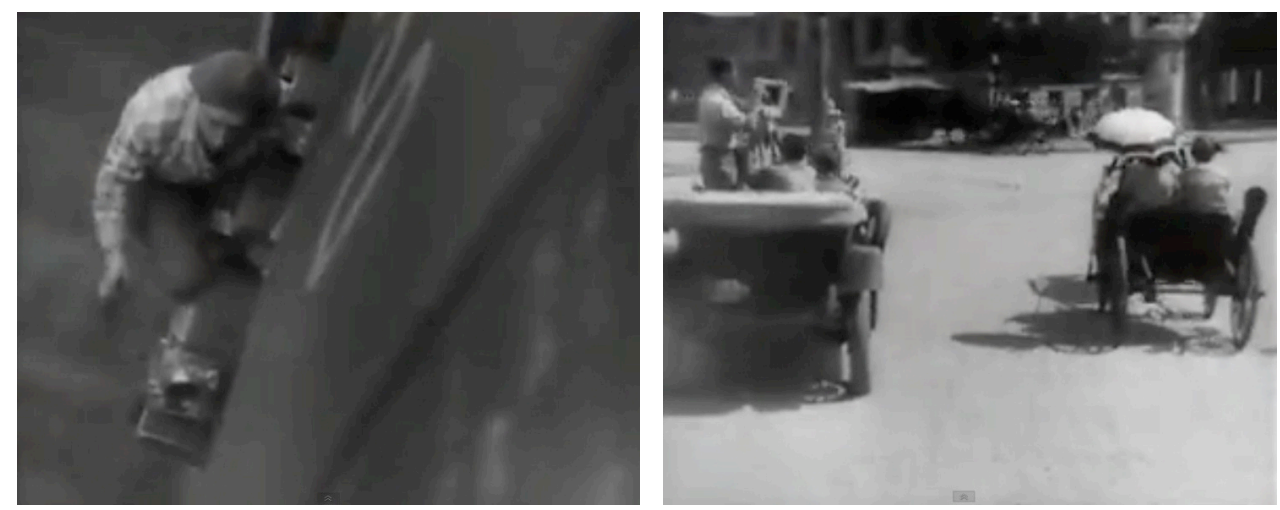

Fotogramas de El hombre de la cámara (Dziga Vertov, 1929) que ilustran la teoría del Cine-Ojo: F1 la cámara en las vías del tren, F2 la cámara sobre un puente, F3 la cámara en el vagón del tren, F4 la cámara en un automóvil.

Ahora bien, a pesar de esta multiplicidad de perspectivas que encontramos en las obras del 15M, es difícil encontrar imágenes diferentes o encuadres insólitos. La gran mayoría de los cineastas-militantes opta por filmar desde un lugar muy localizado y codificado y por ello todos ellos repiten incansablemente planos de la masa de manifestantes gritando consignas y de los que toman la palabra bien en las asambleas, bien en las entrevistas, mientras que olvidan registrar ese "cualquier lugar" que es tan importante para el realizador de El Hombre de la cámara (1929).

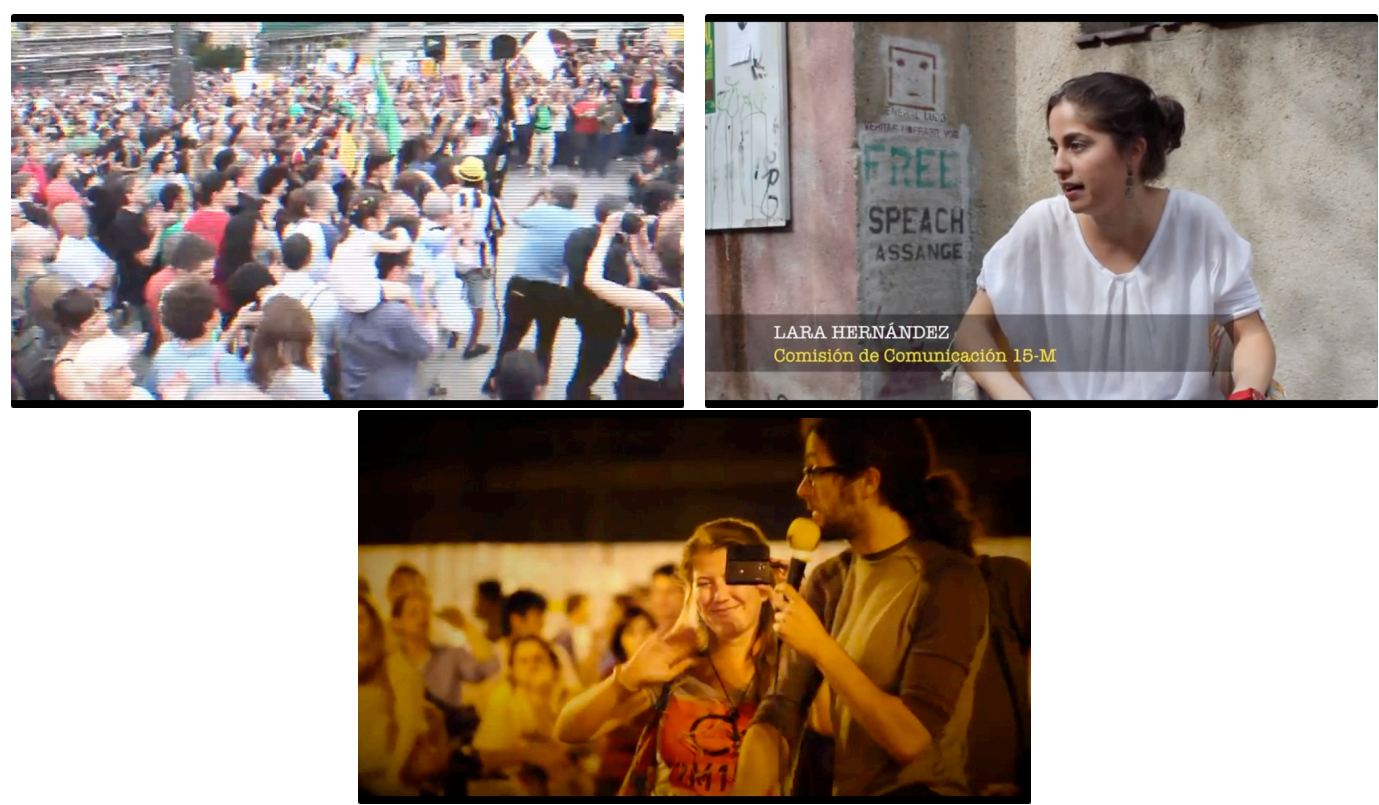

Fotogramas de 15M. En nombre de la democracia (Fernando Santise, 2011). F5 la masa de manifestantes, F6 el busto parlante, F7 el portavoz. 

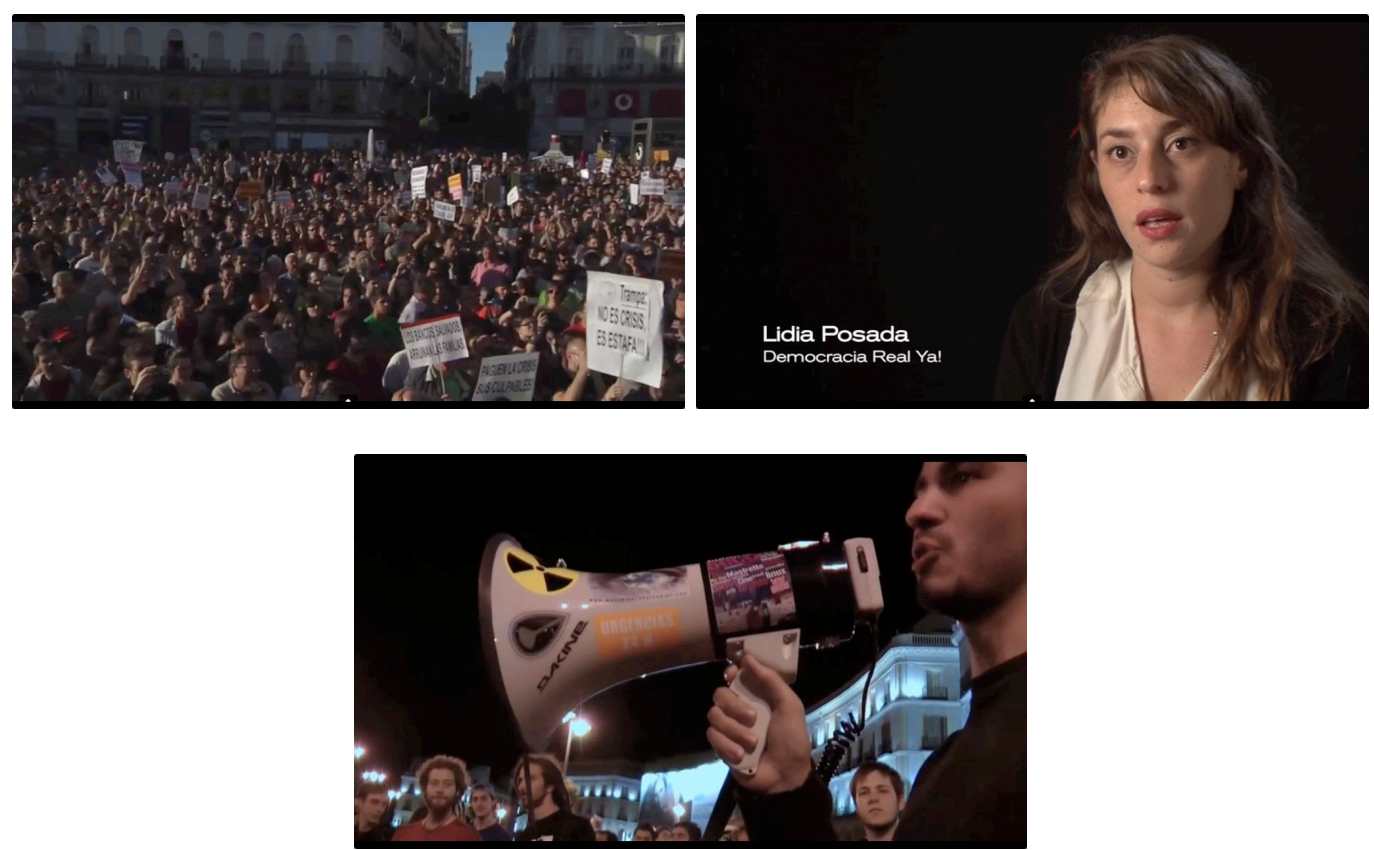

Fotogramas de Excelente. Revulsivo. Importante. Una visión muy personal del 15M (S. Grueso, 2012). F8 la masa de manifestantes, F9 el busto parlante, F10 el portavoz.
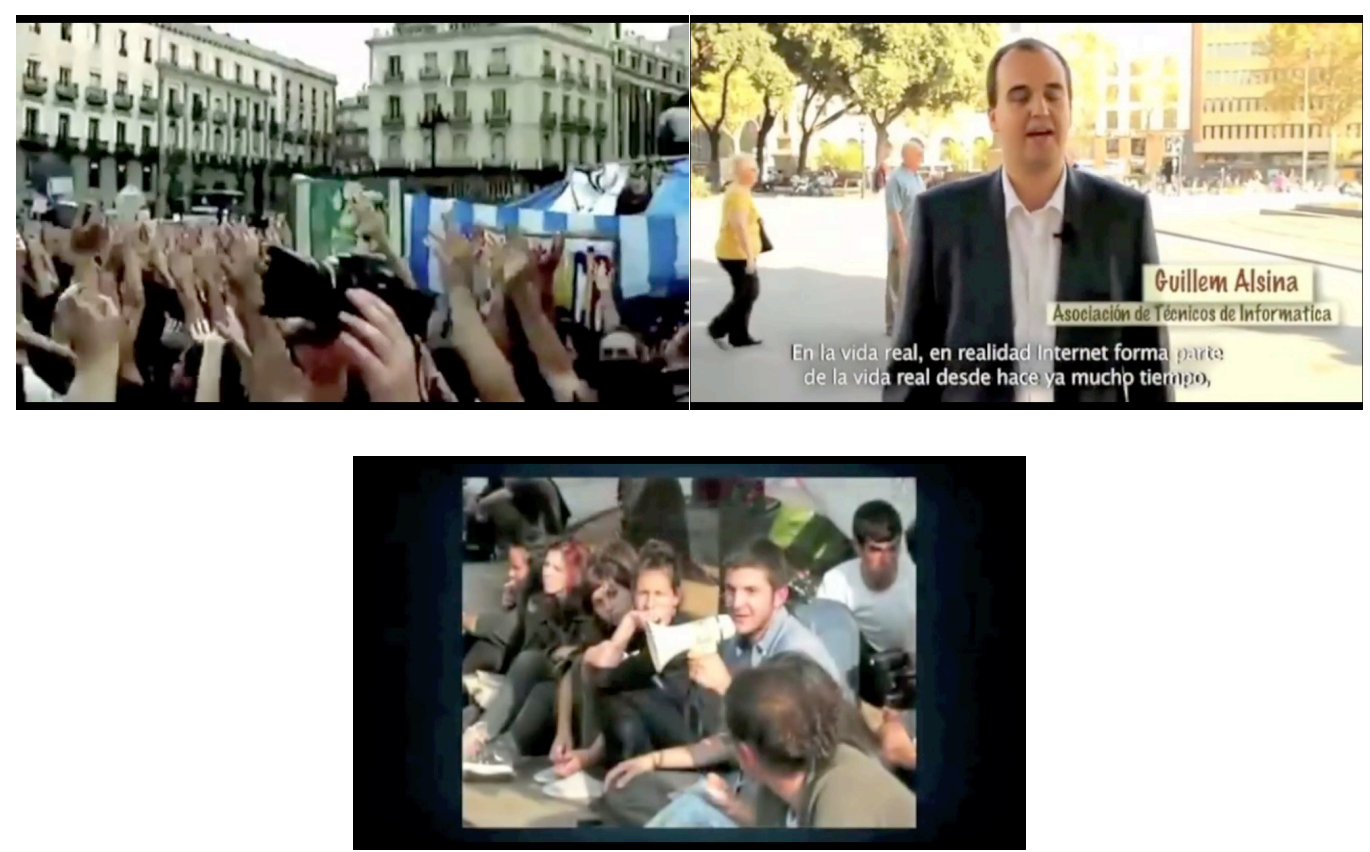

Fotogramas de Docuindignados (Anónimo, 2011). F11 la masa de manifestantes, F12 el busto parlante, F13 el portavoz.

En realidad, las múltiples imágenes filmadas por los diversos cineastasmilitantes no son muy diferentes entre ellas. Lo coherente con la lógica del 15M, por ejemplo, sería filmar más contraplanos de las asambleas, lanzar el encuadre sobre los que escuchan y no tanto sobre los que hablan. Algo que defiende, 
desde su experiencia personal, el cineasta Isaki Lacuesta: "Un chico me reprochó que no filmara los discursos sino a la gente que escuchaba, votaba, aplaudía manos en alto, se besaba, comía o jugaba a las cartas. Le respondía que ya había otras cámaras grabando a los ponentes y que yo hacía el contraplano" (2011, p. 66). Porque de lo que se trata en este movimiento es de visibilizar la voz silenciada. De hecho, las películas del $15 \mathrm{M}$ deberían ser un contraplano tanto de las imágenes hegemónicas de los mass media como de las imágenes de las cámaras de vigilancia. Es importante buscar, por tanto, esas otras imágenes que contrabalanceen las imágenes del poder. Y lo mismo con los planos-detalle que son esos pequeños átomos que, como en la teoría del caos, hacen que el todo se transforme y que en estas producciones brillan por su ausencia. La filmación de lo otro y de lo pequeño serían el contrapunto y la crítica de los productos audiovisuales del mainstream que siempre giran en torno a "lo uno" del primer plano y "lo grande" del plano general. O lo que es lo mismo: "lo uno" del sujeto aislado y "lo grande" de la masa indiferente. La clave está en sol (Comité de Acción-Artes Escénicas-Música del 15M, 2011) es el único producto audiovisual que consigue filmar lo pequeño: manos tocando percusiones, manos golpeando sartenes y cacerolas, manos cocinando, manos trabajando. Toda una muestra micropolítica de los átomos que piedra a piedra, imagen a imagen, componen la insurgencia.
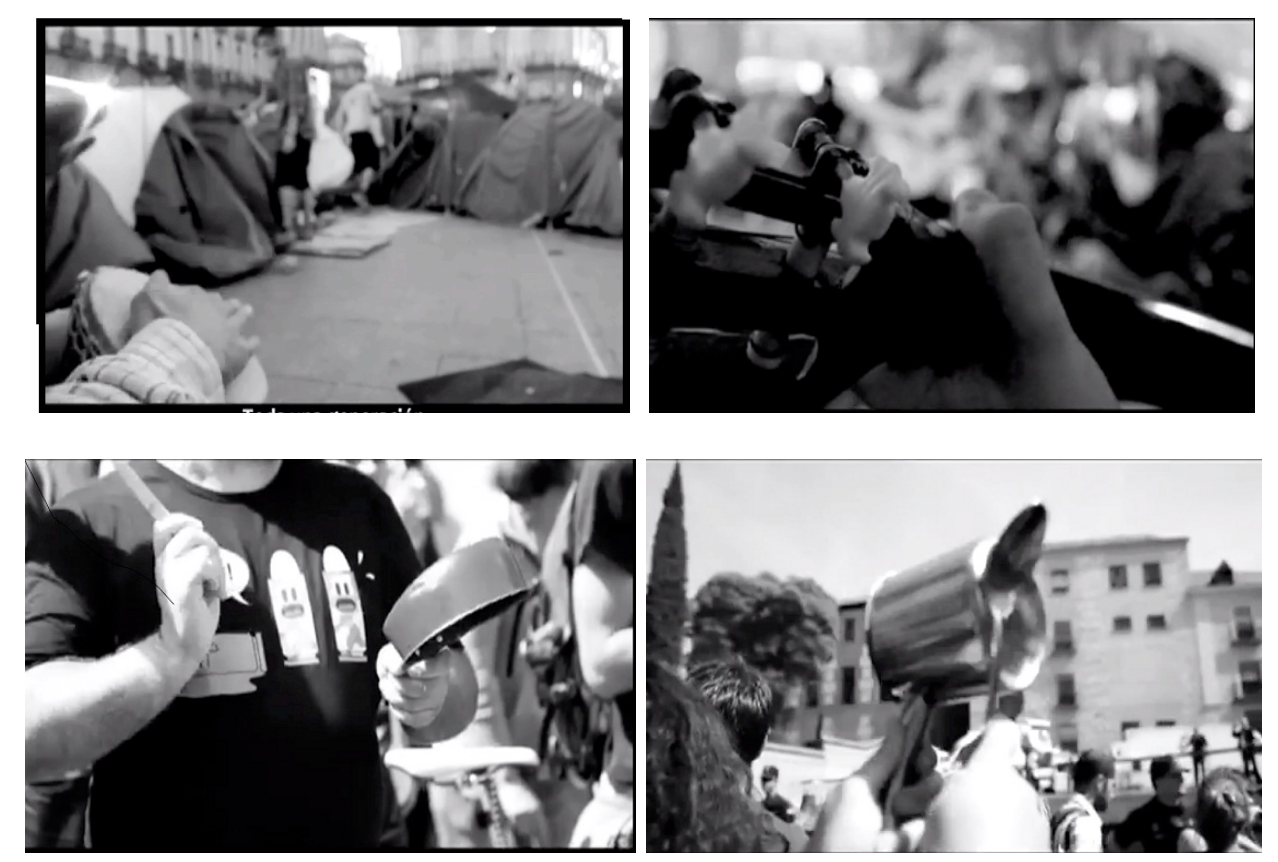

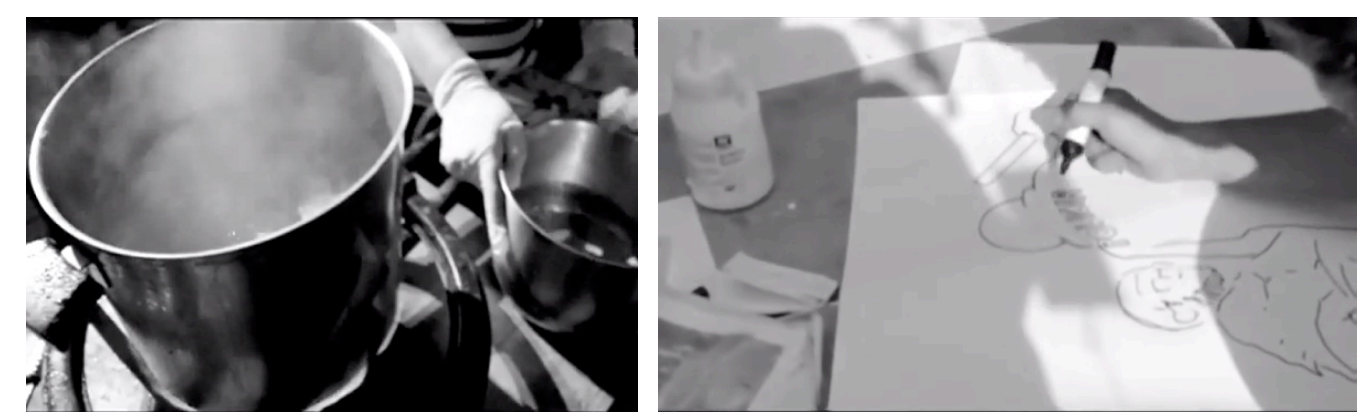

Fotogramas de La clave está en sol (Comité de Acción-Artes Escénicas-Música del 15M, 2011). F14, F15, F16, F17, F18 y F19 muestran la importancia de filmar lo pequeño.

En definitiva, tanto la práctica de la heterofonía en la banda de sonido como la práctica de filmación de "cualquier lugar" -sobre todo de lo otro y de lo pequeño- en la banda de imagen serían los dos estilemas básicos para configurar una enunciación plural. Serían los dispositivos estéticos afines y congruentes con las prácticas de acción social del 15M.

\subsection{Representación múltiple}

Al igual que en el nivel de la enunciación, en el nivel de la representación también son imprescindibles estrategias que produzcan pluralidades $\mathrm{y}$ multiplicidades coherentes con el proceso constitutivo de las asambleas del 15M. Es casi un efecto inevitable: si construimos una enunciación colectiva a partir de voces en off por medio del dialogismo y de las imágenes cualesquiera en busca de la ubicuidad vertoviana, es decir, mostrando lo otro y lo pequeño, entonces las representaciones audiovisuales ya estarán atravesadas por la diferencia. Se trata de construir las imágenes de la lucha social común a partir de la elaboración y la imbricación de unos sonidos e imágenes comunes que no sean redundantes y que sirvan para que el espectador configure una tercera imagen virtual que es parte de un proceso activo de producción mental. Por tanto, construir representaciones audiovisuales múltiples alimentará la capacidad cognitiva activa de los espectadores y supondrá un esfuerzo por la emancipación especular. Algo absolutamente coherente con el movimiento que solicita de la ciudadanía un papel más activo, comprometido y crítico con las prácticas de la clase política dominante, que hasta ahora son las únicas que disponen de ventanas -prensa, cine, TV- para emitir sus imágenes. De alguna 
manera, al inicio del movimiento del $15 \mathrm{M}$ se observó como las imágenes del poder político y económico pretendían destruir y deslegitimar a las imágenes de la ciudadanía. Trataban de destruir a su contrario: la sociedad civil. Por el contrario, la razón común se rebeló contra esta mirada unilateral y unió sus fuerzas para configurar otras imágenes: las suyas. Mucho más plurales y democráticas.

Esta estrategia de componer una representación múltiple es la que se puso en práctica en la acampada de Sol en la intervención artística del cartel de la campaña publicitaria de L'Oreal protagonizada por Paz Vega. A la imagen de la actriz se le superpusieron una serie de imágenes y slogans que cambiaban el sentido comunicativo del anuncio y que suponían una práctica de la reapropiación y de la descontextualización de las imágenes. Una práctica del remix y del collage (Tascón \& Quintana, 2012, p. 44) que debería inspirar las producciones audiovisuales del $15 \mathrm{M}$. En cierto modo, una asamblea es una forma de collage y de remix político.

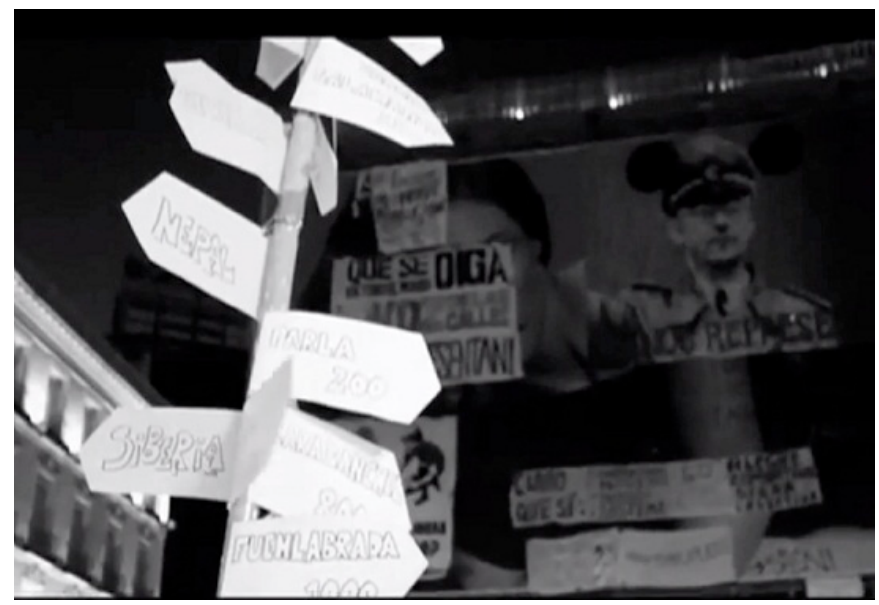

F20 muestra la imagen de Paz Vega en la campaña de L'Oreal sometida a un remix estético-político.

Ahora bien, ¿aparte de esta imagen reapropiada de Paz Vega encontramos alguna práctica de la representación múltiple en los films del 15M? Es cierto que la mayoría de los documentales son muy planos desde el punto de vista estético y muy poco experimentales. La mayoría de las imágenes son planos generales de las asambleas -encuadrando casi siempre a los sujetos que hablan- y de los sujetos entrevistados en primer plano. Sin embargo, podemos encontrar 
algunos ejemplos de representaciones múltiples, de imágenes que hacen uso del collage y la reapropiación.

En Excelente. Revulsivo. Importante. Una visión muy personal del 15M encontramos varias portadas de periódicos superpuestas y girando y mostrando su perspectiva sobre el 15M. Asimismo, en Docuindignados encontramos una serie de imágenes mosaico donde vemos imágenes de Siria, Islandia, Libia y Egipto y que configuran una representación múltiple.

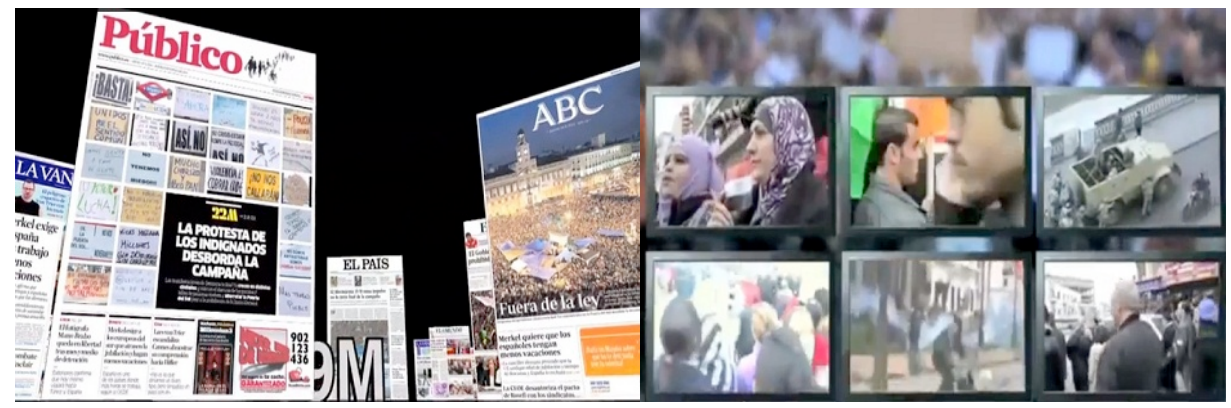

Fotogramas que ilustran la imagen múltiple. F21 composición con diversas portadas de periódicos, F22 imágenes mosaico de diversas movilizaciones sociales.

Indudablemente estas estrategias son similares a las adoptadas por Jean Luc Godard en su etapa maoísta -por ejemplo en Ici et ailleurs- cuando aseguraba que su intención no era mostrar las imágenes de las luchas revolucionarias sino más bien la relación que existía entre ellas: "No tratamos de mostrar imágenes sino relaciones entre imágenes" (1970, p. 13)

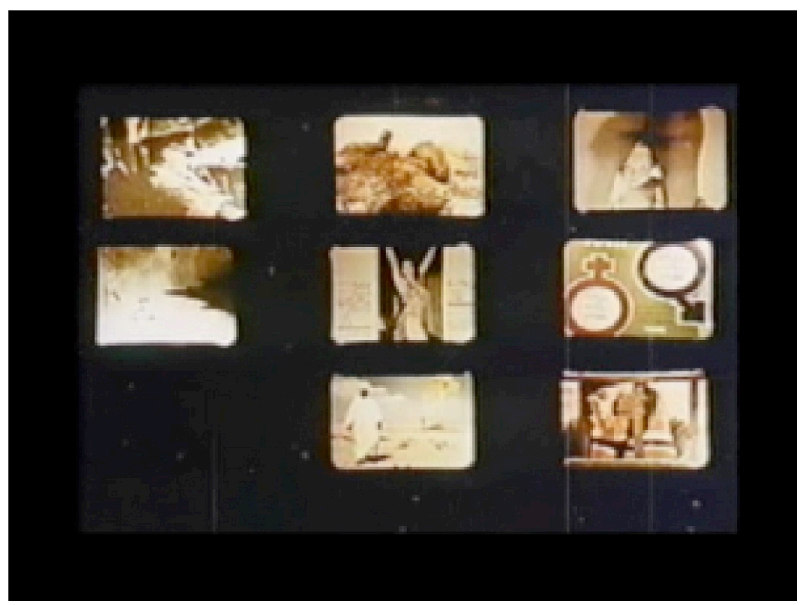

Fotograma de Ici et ailleurs (Jean-Luc Godard, 1970). F23 ejemplo de imagen mosaico. 
La metodología de Godard tiene como finalidad la liberación de las imágenes de algo así como un lugar natural, -casi en sentido aristotélico-, delimitado y cerrado, para ponerlas en interrelación con la idea de configurar una multiplicidad diferencial. Esta práctica la podríamos resumir del siguiente modo: dada una imagen se trata de buscar otras imágenes para que entre ambas se genere una tercera imagen que adopta un sentido virtual ya que ésta sólo existe en la mente del espectador. Ahora bien, esta imagen mental es para Godard la verdadera imagen: la imagen liberada del tiempo cronológico que impone la secuencia cinematográfica gracias a la puesta en contacto de elementos dispares que hacen surgir una fricción, una fractura que es justamente la que potencia el pensamiento activo, la que hace irrumpir algo nuevo.

De este modo, la estrategia coherente con las acciones del $15 \mathrm{M}$ para realizar una representación múltiple tendría que hacerse cargo de este estilema godardiano. Se trata de realizar un film donde se vaya progresando de diferencia en diferencia, donde las imágenes y los sonidos pierdan su sentido convencional y adquieran connotaciones no previstas y multidirrecionales, creando circuitos que exploren las posibilidades del cine, sus límites, y que no se elaboren según los modos y las formas impuestas por la ideología visual dominante.

\subsection{Narración abierta}

La lógica de las prácticas asamblearias del 15M muestra un carácter abierto, puesto que en la toma de decisiones se van acumulando las perspectivas y los puntos de vista de cara a enriquecer la propuesta sometida a votación. Esta práctica de producción política en estructuración permanente debería de ser tenida en cuenta por los militantes que pretendan producir películas afines, películas que sean en la forma y no sólo en el contenido solidarias con este movimiento social. Por ello, habría que indagar si las producciones audiovisuales del $15 \mathrm{M}$ hacen uso de una estructura narrativa abierta y de qué modo lo pone en práctica.

Pero antes, hay que apuntar -aunque sea de manera sucinta- como la lógica narrativa dominante emerge dentro una estructura social determinada. 
Sabemos que el sistema de una democracia representativa establece jerarquías y lugares bien definidos y, por tanto, conforman a una estructura cerrada. De ahí que el modelo narrativo dominante parta también de estructuras cerradas y fosilizadas. El modelo funcionalista que Vladimir Propp vislumbra en los cuentos maravillosos y que ha sido asumido por las historias de la cultura dominante es el paradigma de relato profundamente cerrado y formalizado ya que para el autor ruso "no hay más que un único eje para todos los cuentos maravillosos” (1998, p. 34). Resulta tan cerrado como el modelo dialéctico que Hegel propone para la Historia ya que en su sistema no hay apertura alguna ni espontaneidad. Todo está decidido y ordenado en lo universal: "el desarrollo completo de la forma permite determinar con seguridad las diferencias y ordenarlas en sus relaciones fijas" (1993, p. 13) Sin duda entre Hegel y Propp hay una filiación subterránea, en el sentido en que tanto la lógica hegeliana como la teoría del relato de Propp desarrollan un movimiento o un gesto que supone el desarrollo de una idea (o personaje) a través de una trama de tesisantítesis (o héroe-oponente) que tiende a un fin, ya sea el fin de la Historia (Hegel) o el de la historias (Propp).

Esta univocidad narrativa ha sido criticada por las corrientes del pensamiento estructuralista y el postestructuralista. Las narraciones de la modernidad, según estos pensadores afiliados al antihegelianismo, ponen de manifiesto una ruptura de la estructura del relato clásico. Para Julia Kristeva el texto "construye una zona de multiplicidad de señales e intervalos cuya inscripción no centrada pone en práctica una polivalencia sin unidad posible" (2001, p. 12). Esta definición sin duda es válida para las narraciones de la modernidad. En Roland Barthes ya "no se trata de manifestar una estructura, sino, en la medida de lo posible, de producir una estructuración" (2001, p.15). Y Gilles Deleuze y Féliz Guattari proponen el concepto de rizoma que es solidario con la apertura narrativa ya que el rizoma "procede por variación, expansión, conquista, captura, inyección...siempre desmontable, alterable, modificable, con múltiples entradas y salidas, con sus líneas de fuga [...] es un sistema acentrado, no jerárquico y no significante [...] sin memoria organizadora o autómata central" (2000, p.19). Todas estas operaciones de "acentramiento", de "estructuración” y de "variación 
y expansión” las consideramos análogas a las prácticas políticas del 15M. Ahora bien ¿ocurre lo mismo con las narraciones militantes realizadas hasta la fecha?

Si bien es verdad que la mayoría de los documentales siguen la lógica del copyleft, ejemplo paradigmático de ello es Excelente. Revulsivo. Importante. Una visión muy personal del 15M, esto es, de copiar lo mejor que hacen otros e incluirlo cada cual en su producción audiovisual, lo que supone cierta quiebra y apertura de la narración, también es cierto que ninguno de ellos tiene el carácter abierto, alterable, estructurante y modificable que se encarna en los modos de actuar del 15M. Sin embargo, este documental introduce una novedad que implica una cierta apertura narrativa ya que en los títulos de crédito aparece una ocupación del documental por un videoclip realizado por otra persona donde vemos a una serie de personas haciendo uso contestatario de las nuevas tecnologías: soñando la posibilidad de producir un cambio social desde casa con conexión a internet. Grueso relata como abrió una convocatoria para que otros realizadores pudiesen ocupar los títulos de crédito de su película y asegura que no sabía de antemano como era esa pieza audiovisual. Esta sí es, por tanto, una posible táctica de enunciación plural y de narración abierta que abre una puerta a la discusión dialógica, una apertura narrativa.

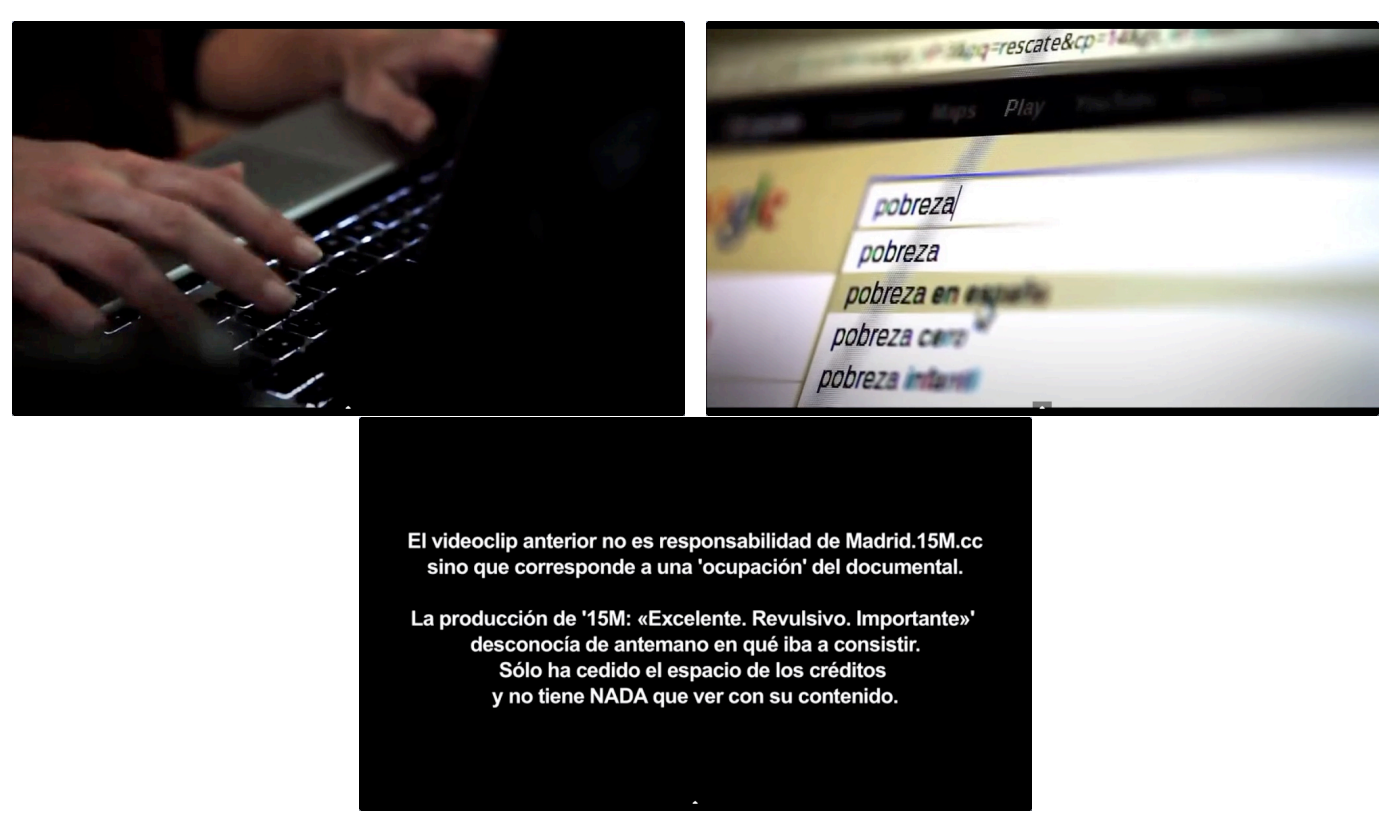

Fotogramas de la pieza audiovisual que ocupa el documental Excelente. Revulsivo. Importante. Una visión muy personal del 15M. F24, F25 y F26. 
A pesar de esta acción singular, casi todas las películas del 15M son demasiado cerradas ya que imponen un sentido único en tanto que son películas que no son discutidas, rechazadas, desviadas, comentadas o remontadas. Por ello, hay que potenciar que la obra esté abierta a la libre discusión de quien la va a visionar.

Nuevamente, en nuestra labor por encontrar recursos formales adecuados a la productividad política, consideramos necesario que los cineastas militantes revisen dos prácticas pretéritas que sí dan cuenta de esta modalidad de apertura en la narración. Estas estrategias son el cine-tren de Aleksandr Ivanovitch Medvedkin y del etno-diálogo de Jean Rouch.

La estrategia de Medvedkin la encontramos expuesta en su artículo "El tren cinematográfico", donde explica la metodología que desarrolló para la denuncia de aquellos errores que paralizaban la revolución en la Rusia socialista. Para ello, equipó los vagones de un tren con todo lo necesario para la filmación y el montaje de estas películas, con la idea de recorrer el país en busca de repuestas a dichos problemas. A continuación, proyectaba lo filmado en los diversos centros de producción, minas e industrias, y luego "se discutía el film" entre todos (1998, p.130). En algunos casos, se volvían a montar los films con material filmado de los debates. Esta práctica es una forma posible de apertura narrativa que fomenta sin duda la participación activa de los sujetos.

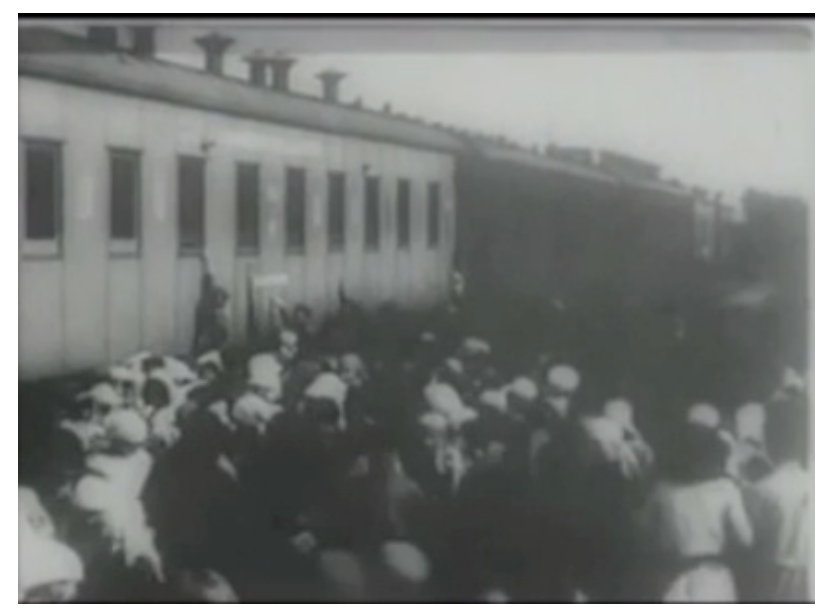

El cine-tren como ejemplo de trabajo político-cinematográfico en constante discusión. F27 fotograma del cine-tren de Medvedkin. 
La estrategia de Jean Rouch consiste en establecer una apertura al otro, un diálogo con los sujetos filmados. En Moi un noir (Rouch, 1958), ensayo documental filmado en Costa de Marfil donde cuenta las dificultades con las que se encuentran un grupo de inmigrantes nigerinos, Rouch propone una técnica de apertura que parte de la proyección del material filmado a las personas con las que ha trabajado con la intención de buscar críticas y comentarios que le permitan rehacer el material filmado: "El cine era una instrumento de investigación insustituible, no solo por $\mathrm{su}$ facultad de reproducir indefinidamente lo que ha sido observado, sino por la posibilidad de proyectar el documento extraído ante las personas observadas y estudiar con ellas a partir de las imágenes su comportamiento" (1998, p.161) De este modo, el film no se acaba tras la proyección pues su propia temática consiste en el dialogo y la colaboración que se da entre el cineasta y los actores al visionar el material registrado. Así, el cine es utilizado por el cineasta francés para poner en marcha un modo de participación colectiva ya que de este dialogo surgen dudas, preguntas y comentarios que luego se incluirán en el montaje definitivo.

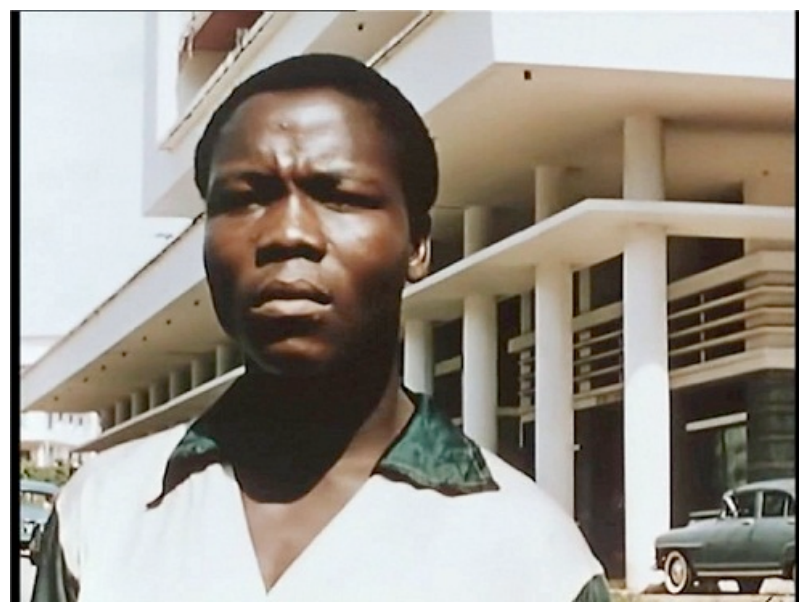

Fotograma de Moi, un noir (Jean Rouch, 1958). Sobre la imagen F28 uno de los protagonistas comenta su propia imagen tras ver el film. En el montaje definitivo, Rouch incluyo en la voz en off su comentario: "No, yo no me llamo Edward G. Robinson. Es un sobrenombre que he tomado, y así me llaman mis compañeros. El sobrenombre, Edward G. Robinson, es porque me parezco, tengo cierto aire a Edward G. Robinson, cuando veo sus películas en el cine. No digo mi verdadero nombre porque soy extranjero en Abidjan. Yo vengo de Níger, a $2000 \mathrm{~km}$ de aquí, Abidjan”. 
En definitiva, el work in progress propuesto por ambos cineastas, esto es, la consideración del film como algo no terminado ni clausurado, siempre en marcha y en mutación, es un estilema que armoniza con las tácticas mutantes de las asambleas horizontales de la democracia participativa ensayada en el 15M. Algunos cineastas militantes como Gerardo Tudurí han hecho hincapié en estas cuestiones al proponer que las películas del 15M tenían que partir de un "guion consensuado” y un “montaje debatido” (Tudurí, 2011, p. 66).

\section{La distribución audiovisual de lo común}

Planteados los problemas a los que se enfrenta el movimiento $15 \mathrm{M}$ en el ámbito de la producción audiovisual, toca valorar de qué modo distribuir las imágenes. Para ello, resulta fundamental, por un lado, valorar los aspectos positivos y negativos del uso de internet como herramienta de acción social; y por otro lado, considerar si el archivo multimedia es la forma (o más bien la no-forma) audiovisual más adecuada para las prácticas participativas de los nuevos movimientos sociales.

\subsection{La ocupación de los canales de información}

Habida cuenta de que los medios de información y comunicación tradicionales están en manos de las corporaciones económicas y políticas contra las que se posicionan, los militantes del 15M esquivan dichos medios y deciden realizar sus prácticas de lucha social en la red. Hay un esfuerzo considerable de un gran número de ciudadanos que se implican en la distribución de los productos audiovisuales en redes sociales como facebook, vimeo, twitter, youtube, etc. Se trata de ocupar no solo el espacio público de las plazas sino también el espacio de los entornos virtuales. Esta es la consigna: “Tomar el espacio público, implica ocupar también el espacio audiovisual y los canales de información" (Ortiz, 2011, p. 64). Ahora bien, este Edén prometido por las redes sociales donde se sueña que mediante la coordinación colectiva en el espacio virtual cabe la posibilidad de construir un territorio de resistencia activa ante la hegemonía de la ideología dominante no deja de ser un acto de contestación o devenir on line que pierde toda su fuerza y potencia critica. 
Ante esta polémica en torno al modelo de la reproductibilidad telemática toca valorar una serie de pros y de contras. Es cierto que la interacción social en internet tiene aspectos positivos que suponen un ejercicio de crítica a las formas de organización social tradicionales y que posibilitan estructuras de interacción más participativas y democráticas. Pero también resultan aspectos negativos alienantes derivados de su status virtual.

Entre los aspectos positivos hay que destacar dos fundamentales: la idea de un conocimiento compartido y la creación de una red descentralizada de encentro horizontal entre ciudadanos.

En primer lugar, hay que señalar que estas producciones que hemos analizado están todas bajo Licencia Creative Commons. Todas ellas se adhieren a la idea de que la creación tiene que ser compartida, lo que trae como consecuencia que esta forma de distribución sea una forma de hacer política ya que fomenta el conocimiento compartido. Muchos activistas, cineastas amateur y cineastas militantes se han sumado a esta práctica. Félix Pérez-Hita, por ejemplo, afirma que "una de las tareas más urgentes es ordenarlo y colgarlo en la red a disposición de cualquiera con licencia CC” (2011, p. 67). Estas prácticas de generación de conocimientos y herramientas compartidas está en la base del denominado ciberactivismo, "la idea es: desarrolla herramientas y déjalas a disposición pública. Ya habrá quien sepa qué hacer con ellas, las herramientas no son neutrales. Desde archivos descargables para hacer plantillas, volantes y camisetas, a software libre para hacer y federar blogs, pasando por manuales de resistencia civil no violenta con mil y un pequeños gestos cotidianos que propagar” (De Ugarte, 2007, p. 28). Este saber compartido se enmarca dentro de la cultura altruista del copyleft y de los wikis de los que hace apología, entre otros, el documental Excelente. Revulsivo. Importante. Una visión muy personal del 15M. Y no se trata solo de que su producción y distribución sea colaborativa: también se proponen hackear el engranaje del sistema económicopolítico. 
En segundo lugar, la red potencia la proliferación de formas expresivas que son distribuidas en un espacio abierto, descentralizado y desjerarquizado que fomenta una recepción o un consumo que rompe la lógica de los discursos lineales. Lo importante de esta forma de distribución no es la obra en sí, sino el nuevo modo de interacción social que configura un nuevo espacio público: "El mayor desafío no es el de experimentar nuevas formas de expresión artística sino experimentar una nueva reorganización de la esfera pública” (Brea, 2002, p. 22). Un modo de interacción que tiene similitudes con el propuesto por el 15M. Respecto al movimiento de contestación Yolanda Quintana y Mario Gascón afirman que "su estructura y dinámica son las de una "multiplicidad de actores que actúan en diferentes frentes simultáneamente y que se organizan sin plan previo y sin líder, de forma natural”. Como Internet, es un modelo en red distribuido en el que "todos somos potencialmente activistas" (2012, p. 28). Este modelo organizativo pretende ser horizontal y participativo es bidireccional: va de la plaza a la red y de la red a la plaza. Así lo muestra el vídeo TRON (versión 15M) (Felipe González Gil, 2011). En las imágenes observamos la maravillosa mutación que se establece de las redes de información a la "red" de la ciudadanía.
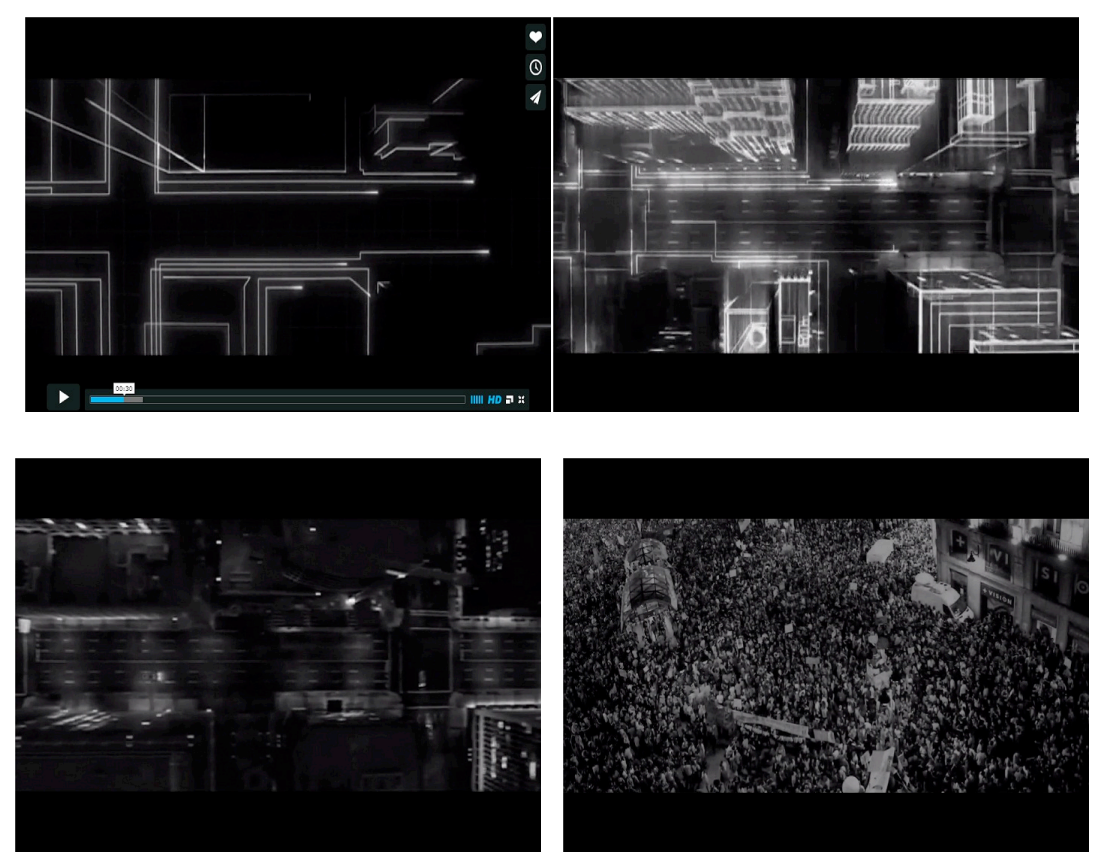

Fotogramas de la película TRON (versión 15M) (Felipe González Gil, 2011). En F29, F30, F31 y F32 el cineasta muestra el paso de las redes e la información a las redes ciudadanas. 
Respecto a los aspectos negativos hay que reseñar una serie de problemas políticos adheridos a la reproducción telemática.

En primer lugar, hay que destacar que uno de los problemas de la distribución on line de los productos audiovisuales del $15 \mathrm{M}$ es que el contenido y las formas estéticas y narrativas decaen y se convierten en un simple efecto de difusión. En internet, la saturación de información provoca la imposibilidad de su digestión y aun así no deja de circular indefinidamente. Es decir: aunque la distribución on line en la red posibilita la creación de un espacio público de interacción donde ningún ente regulativo impone sus reglas, lo cual es coherente con las prácticas de la democracia participativa, también hay que destacar que la localización de los productos en la red virtual hace que su poder para generar debate, discurso y crítica pueda ser desactivado al no hacerse carne en el espacio público real.

En segundo lugar, resulta objeto de crítica que internet sea una tecnología de la información y la comunicación que posibilita una interacción social uniformada. Por muy plurales y múltiples que sean las posibilidades de conexión, relación y comunicación, estas se generan en un espacio no real que nos lleva a perder pie del sentido del mundo. La tecnología ha campando a sus anchas en nuestras vidas y está comenzando a transformar nuestro modo de vivir, de conocer, de pensar. Da la sensación de que el mundo tecnológico está empezando a sustituir al de carne y hueso y que se ha convertido en una especie de ficción generalizada que promete salvarnos del apocalipsis cotidiano.

En tercer lugar, hay que considerar que el streaming, ese dispositivo de emisión en tiempo real utilizado en las movilizaciones del 15M y que elimina la distancia entre la producción, la distribución y el consumo, resulta más tiránico que democrático: "Las sociedades antiguas ponían en práctica velocidades relativas: el navío, el caballo. Estas podían ser democratizadas. En nuestra época la velocidad es absoluta: el tiempo real. Lo propio de la velocidad absoluta es el poder absoluto. Son atributos divinos: ubicuidad, instantaneidad, inmediatez. Visión total. Esto es más una tiranía que una democracia” (Virilio, 2005, p. 18). La posibilidad tecnológica de poder grabar cualquier cosa y en 
cualquier lugar y poderlo retransmitir en tiempo real es más propio de una utopía dictatorial, delirante y demoníaca que de democracias ilustradas. Esa ubicuidad divina resulta francamente terrorífica.

\subsection{El archivo como elemento distributivo de una no-forma audiovisual}

Respecto a la valoración del archivo como nueva forma audiovisual hay que apuntar que gracias a la reproductibilidad telemática es posible un modelo de almacenaje de los contenidos producidos que no deja de crecer a medida que se agregan nuevos documentos. El Colectivo Los Hijos se pregunta por la forma que debería de tener un documental y acude a la noción de archivo en tanto que memoria colectiva, informe y anónima que parece emparentada con la lógica del movimiento 15M: “¿Qué forma debería tener un documento audiovisual sobre el movimiento 15M? ¿Lo debería firmas un autor, un colectivo de varias personas? Quizá todo lo que hemos grabado en las diferentes plazas y asambleas (cada ciudadano con sus dispositivos móviles, a título personal), debería de ponerse a disposición de un archivo mayor, de una memoria numerosa y múltiple, en constante crecimiento" (2011, p. 65). Compartimos con los autores de Los materiales esta defensa de generación de una memoria construida desde la pluralidad de voces y miradas anónimas ajena al estatismo de los films ya hechos y clausurados. Esta memoria no debería de tener marca de autor, ni debería tener una estructura jerárquica ni vertical. Es suma: debería ser el elemento distributivo de una no-forma audiovisual. Pero ¿qué hacer con el archivo? ¿Qué se esconde en sus entrañas? ¿Cómo usarlo y ponerlo en práctica? Jacques Derrida afirma que eso sólo lo sabremos en el porvenir: "Es una cuestión de porvenir, la cuestión del porvenir mismo, la cuestión de una respuesta, de una promesa y de una responsabilidad para mañana. Si queremos saber lo que el archivo habrá querido decir, no lo sabremos más que en el tiempo por venir" (1996, p. 44). Quizá Derrida se equivoca. Para nosotros el archivo tiene que ser continuamente trabajado, desestructurado, sometido a variación no con una vana vocación artística sino con la intencionalidad de sacar de él una fuerza transformadora, una visión que conmueva, haga pensar y promueva la acción democrática. 
Esta idea del archivo ha sido compartida por otros cineastas militantes. Áurea Ortiz dice que las imágenes del 15M configuran "relatos generados desde muchas instancias: las de cada uno de los ciudadanos que suben las imágenes a la red y las comparten” (2011, p. 64). Flavio García afirma que "quizá la obra audiovisual sobre el $15 \mathrm{M}$ sea internet mismo: un work in progress constante, una obra colectiva, no jerarquizada, de creación horizontal, participada, comentada y compartida por todos en Youtube o Vimeo, actualizada en tiempo real, y regularmente transmitida en directo. Esto es, un reflejo de la propia movilización” (2011, p.65). Blanca Martinez y Alberto Navas reinciden: “Tenemos la intención de proteger el extensísimo archivo audiovisual de centenares de horas y abrirlo a todo aquel que quiera acceder ya que se trata de material libre" (2011, p. 66). Y las propuestas de un archivo se multiplican hasta que apareció por fin $15 \mathrm{Mcc}$, una de las propuestas archivísticas de relato colectivo multimedia sobre los acontecimientos y evoluciones del movimiento 15M. Un archivo que presenta las cualidades de una narración marcada por una enunciación colectiva y abierta al libre intercambio comunicativo.

\section{Conclusiones}

Uno de los problemas que se observan en los documentales del 15M es que son una reproducción del movimiento más que una producción. Habría que hacer un mayor esfuerzo creativo y ser algo más analíticos y críticos para producir obras que sean expresión del movimiento y no un mero reflejo. Todo producción de crítica social supone siempre una ruptura, la irrupción de una novedad, una brecha; mientras que la reproducción nos adentra en una espacio seguro. La reproducción es tautológica; la producción supone adentrarse en tierra ignota. Hay muchas maneras de trabajar el material capturado, de entresacar de él esa novedad arraigada a la producción. No vale la simple exposición. Hay que cuestionar las propias formas de filmación que están claramente marcadas por la ideología dominante. Las cámaras no son inocentes en la medida en que están construidas según la perspectiva clásica, según el orden de la representación que es justamente contra lo que se está luchando. 
Por ello, hemos creído que era el momento de evaluar las formas y las prácticas documentales que se han implantado durante el $15 \mathrm{M}$, a la vez que resultaba necesario volver la mirada al pasado para apropiarse, siguiendo la lógica del remix, de las técnicas de ruptura de cineastas como Dziga Vetov, Jean Luc Godard, Jean Rouch y Medvedkin. Ellos han sabido combinar como nadie sus discursos políticos y artísticos.

Además, hemos considerado oportuno definir qué es una película política. Para hacer una película política no basta con quedarse en la superficie temática. Su modo de producción, distribución y consumo también ha de ser político. Muchos de estos documentales -no los que hemos analizado pues estos poseen Licencia Creative Commons- instrumentalizan la movilización social para obtener un beneficio económico, lo cual entra en contradicción con los presupuestos ético-políticos del movimiento. Otros están subvencionados por alguna institución estatal.

En este sentido, las imágenes del 15M deberían aspirar a ser el contraplano de las imágenes generadas por las instancias de poder que territorializan el conjunto de los medios de comunicación: en la prensa, en la televisión, en el cine. Estas imágenes deberían servir para generar un pensamiento crítico contra el imperialismo de la opinión: imágenes al asalto de la verdad y el conocimiento en contra de la doxa impuesta por los mass media que no hacen otra cosa que seguir los dictados de sus amos. De algún modo, las producciones audiovisuales del 15M tendrían que hacer una revolución pareja a la revolución socrática: buscar la verdad, abrir una ventana al conocimiento.

Ahora bien, lo coherente radica en que esta verdad crítica con el poder emerja a partir de la combinación y la armonía de las imágenes y los sonidos registrados por una pluralidad de sujetos, haciendo uso de representaciones múltiples y de narraciones abiertas. Las imágenes del 15M deberían estar recogidas por una multitud de cineastas-militantes que revelen la razón común, que fomenten la emancipación a través de la imagen, que tomen al asalto el sistema audiovisual, que luchen contra el ruido mediático y contra el sentido único. 
En suma, que hagan del cine su campo de batalla pues "todo conflicto es un campo de percepción. Se trata de ver venir al otro. Antes se hacía la guerra con mapas, la geografía servía para hacer la guerra. Ahora la guerra es de imágenes: las cámaras sirven para localizar al adversario. La guerra se convierte en una película de guerra: ya no se trata de mapas sino de películas (Virilio, 2005, p. 28).

\section{Referencias bibliográficas}

Althusser, L. (1975). Escritos. Barcelona: Laia.

Barthes, R. (2009). Lo obvio y lo obtuso. Barcelona: Paidós.

Barthes, R. (2001). S/Z. Madrid: Siglo XXI.

Brea, J. L. (2002). La era postmedia. Salamanca: Editorial CASA.

Caicedo, J. (2003). Dialógo, dialogismo e interlocución. Enunciacion (8). Recuperado

Colectivo Los Hijos (2011). Imaginar la forma (o no-forma). Cahiers du cinema. España. (47).

Daney, S. (2012). "Prefacio a Ici et ailleurs". Recuperado en http://intermediodvd.wordpress.com/2012/09/05/prefacio-a-ici-etailleurs-godardmieville-porserge-daney/

Deleuze, G. \& Parnet, C. (2004). Diálogos. Valencia: Pretextos.

Deleuze, G. \& Guattari, F. (2000). Mil mesetas. Valencia: Pretextos.

Derrida, J. (1996) Mal de archivo: una impresión freudiana. Madrid: Trotta.

De Ugarte, D. (2007). El poder de las masas. Barcelona: El cobre.

Foucault, M. (2002). La arqueología del saber. Barcelona: Siglo XXI.

García, F. (2011). Con urgencia y en directo. Cahiers du cinema. España. (47)

Godard, J.L. (1970) Godard chez les feddayin. Entrevista en $L$ 'express, 27 julio 1970.

Hegel, G. W. F. (1993). Fenomenología del espíritu. México: FCE.

Kristeva, J. (2001). Semiótica. Madrid: Fundamentos.

Lacuesta, I. (2011). Un metro más. Cahiers du cinema. España. (47).

Martínez, B. \& Navas, A. (2011). Un archivo libre y accesible. Cahiers du cinema. España. (47). 
Medvedkin, A. (1998). El tren cinematográfico. Joaquim Romaguera y Homero Alsina (Eds.). Textos y manifiestos del cine. Madrid: Cátedra.

Negri, A. \& Hardt, M. (2006). Multitud. Barcelona: Mondadori.

Nichols, B. (1997). La representación de la realidad. Barcelona: Paidós.

Ortiz, A. (2011) Imágenes 15M. Cahiers du cinema. España. (47).

Pérez-Hita, F. (2011). En la tele, debajo del fútbol están las plazas. Cahiers du cinema. España. (47)

Propp, V. (1998). Morfología del cuento. Madrid: Akal.

Rouch, J. (1998). ¿El cine del futuro? Joaquim Romaguera y Homero Alsina (Eds.). Textos y manifiestos del cine. Madrid: Cátedra.

Tascón, T. \& Quintana, Y. (2012). Ciberactivismo. Las nuevas revoluciones de las multitudes conectadas. Madrid: Catarata.

Tudurí, G. (2012). La politica de la colectividad. Recuperado en cinesinautor.blogspot.com.

Tudurí, G. (2011). Denuncia de un sistema audiovisual. Cahiers du cinema. España. (47).

Vertov, D. (2011). Memorias de un cineasta bolchevique. Madrid: Capitan Swing.

Virilio, P. (2005). Cibermundo, la política de lo peor. Madrid: Cátedra.

Wu Ming (2002). Esta revolución no tiene rostro. Madrid: Acuarela.

\section{Filmografía}

15M. En nombre de la democracia (Fernando Santise, 2011)

15M. La revolución como una de las Bellas Artes (Iván Cuevas, 2011)

Docuindignados (Anónimo, 2011)

Excelente. Revulsivo. Importante. Una visión muy personal del 15M (S. Grueso, 2012)

La clave está en sol (Comité de Acción- Artes Escénicas- Música del 15M, 2011)

TRON (versión 15M) (Felipe González Gil, 2011) 